\title{
Sitaxsentan for the Prevention of Experimental Shunt-Induced Pulmonary Hypertension
}

\author{
BENOIT RONDELET, FRANÇOIS KERBAUL, GABRIELA FLORES VIVIAN, IVES HUBLOUE, SANDRINE HUEZ, \\ PIERRE FESLER, MYRIAM REMMELINK, SERGE BRIMIOUILLE, ISABELLE SALMON, AND ROBERT NAEIJE
}

\begin{abstract}
Laboratory of Physiology [B.R., F.K., G.F.V., I.H., S.H., P.F., S.B., R.N.], Departments of Cardiac and Thoracic Surgeries [B.R.], Department of Cardiology [S.H.], Department of Pathology [M.R., I.S.], Department of Critical Care [S.B.], Hôpital Erasme, Université Libre de B-1070 Bruxelles, Belgium; Department of Critical Care [I.H.], Academisch Ziekenhuis, Vrije Universiteit Brussel, B-1070 Brussels, Belgium; Department of Anesthesiology and Critical Care [R.K.], Hôpital La Timone, F-13385 Marseille, France; Department of Internal Medicine [P.F.], Hôpital Lapeyronie, F-34295 Montpellier, France
\end{abstract}

\begin{abstract}
We previously reported on the partial prevention of experimental shunt-induced pulmonary arterial hypertension (PAH) by the nonselective endothelin (ET) ET-A/ET-B receptor antagonist bosentan. As the respective roles of the ET-A and ET-B receptor signaling in the pathobiology of the disease remain undefined, we investigated the effects of selective ET-A receptor blockade by sitaxsentan in the same early stage PAH model. Twenty-one 3-wkold piglets were randomized to placebo or sitaxsentan therapy (1.5 $\mathrm{mg} / \mathrm{kg} / \mathrm{d}$ ), after anastomosis of the left subclavian artery to the pulmonary arterial trunk or after a sham operation. Three months later, the animals underwent a hemodynamic evaluation, followed by pulmonary tissue sampling for morphometry and real-timequantitative-PCR for ET-1, angiopoietin-1, and bone morphogenetic receptor (BMPR) signaling molecules. Three months of left to right shunting induced an increase in pulmonary vascular resistance (PVR) and medial thickness, an overexpression of ET-1, ET-B receptor, and angiopoietin-1, and a decreased expression of BMPR-2 and BMPR1A. Pretreatment with sitaxsentan prevented shunt-induced increase in PVR and decreased medial thickness by $64 \%$. Sitaxsentan therapy completely prevented the decreased expression of BMPR-2 and limited the overexpression of ET-1, ET-B and angiopoietin-1, and the decreased expression of BMPR-1A. In conclusion, selective ET-A receptor blockade partially prevents shunt-induced PAH. (Pediatr Res 61: 284-288, 2007)
\end{abstract}

$\mathrm{T}$ he pathogenesis of PAH remains incompletely understood $(1,2)$. Because of the therapeutic efficacy of ET receptor blockers, and because BMPR-2 mutation is associated with a high risk to develop the disease, the ET and BMP signaling pathways are each thought to play a major role in the pathobiology of PAH $(1,2)$. We previously reported on a left-toright shunt-induced pulmonary hypertension in piglets as a model for the study of early stage PAH (3-5). This model is characterized by an increase of PVR, medial hypertrophy of the small arterioles, and overexpression of ET-1, ET-B, and

Received July 25, 2006; accepted October 24, 2006.

Correspondence: Benoît Rondelet, M.D., Laboratory of Physiology, Free University Brussels, Erasmus Campus CP 604, Lennik Road 808, B-1070 Brussels; e-mail: benoit.rondelet@ulb.ac.be

Benoit Rondelet was a fellow of the Erasmus Foundation, Belgium.

This study was supported by grant 3.4515.05 of the "Fonds de la Recherche Scientifique Medicale," Belgium, the Foundation for Cardiac Surgery, Belgium, and the European Commission (Contract no. LHSM-CT-2005-018725, Pulmotension).

DOI: $10.1203 /$ pdr.0b013e318030d169
Ang-1, together with decreased expressions of BMPR-2 and BMPR-1A $(4,5)$. Thus, both endothelin and BMP signaling are involved in the early stages of PAH $(4,5)$.

ET-1 interacts with ET-A and the ET-B receptors on pulmonary vascular smooth muscle cells to induce constriction and proliferation (6-9), and with ET-B receptors on pulmonary artery endothelial cells for nitric oxide (NO) modulation of endothelin synthesis (10), endothelin clearance (11), and release of NO and prostacyclin (12). The ET-B receptor is overexpressed in overcirculation-induced PAH models $(4,5,13)$. However, the pathogenetic role of the ET-B receptor in PAH remains undefined, as both the nonselective ET-A/B receptor blocker bosentan and the selective ET-A blockers sitaxsentan and ambrisentan similarly improved PAH patients in randomized controlled trials (14-16). We observed that bosentan therapy prevented the increase in PVR and approximately $70 \%$ of pulmonary arteriolar remodeling in growing piglets with a left-to-right shunt-induced PAH (4). We hypothesized that sitaxsentan, a highly selective ET-A receptor blocker (17), might be even more effective in preventing early PAH by allowing for ET-B receptor-mediated ET clearance and antagonistic prostacyclin and NO release.

\section{MATERIALS AND METHODS}

Twenty-one piglets $18 \pm 1 \mathrm{~d}$ old and weighing $5.4 \pm 0.2 \mathrm{~kg}$ were included in this study. These experiments were conducted in agreement with the guide for the care and use of laboratory animals of the U.S. National Institutes of Heath, and were approved by the committee on the care and use of animals in research of Brussels Free University School of Medicine. The animals were randomized to a sham operation $(n=7)$ or to an anastomosis between the left innominate artery and the pulmonary arterial trunk as previously reported (3-5), followed by randomization to sitaxsentan $1.5 \mathrm{mg} / \mathrm{kg} / \mathrm{d}(n=7)$ or placebo $(n=7)$ administered orally with food for 3 mo.

Hemodynamic evaluation. As previously reported (3-5), the animals were anesthetized and equipped with catheters and an ultrasonic flow probe on the pulmonary artery for measurement of $\mathrm{Ppa}_{\mathrm{m}}, \mathrm{Ppao}_{\mathrm{Psa}}, \mathrm{Q}$, pulmonary arterial flow, and blood gases. PVR was defined by multipoint

\footnotetext{
Abbreviations: Ang-1, angiopoietin-1; BMPR, bone morphogenetic receptor; Ea, pulmonary arterial elastance; Ees, end-systolic elastance; ET, endothelin; ET-A (-B), endothelin receptor-A (-B); MT, medial thickness; PAH, pulmonary arterial hypertension; $\mathbf{P p a}_{\mathbf{m}}$, mean pulmonary arterial pressure; Ppao, occluded pulmonary arterial pressure; $\mathbf{P s a}_{\mathbf{m}}$, mean systemic arterial pressure; PVR, pulmonary vascular resistance; $\mathbf{Q}$, cardiac output
} 
point $\left(\mathrm{Ppa}_{\mathrm{m}}-\mathrm{Ppao}\right) / \mathrm{Q}$ plots obtained by rapid inflation of the inferior vena cava balloon (3-5)

Hemodynamic and blood gases measurements were obtained with animals in steady-state conditions for $60 \mathrm{~min}$, after shunt closure. After the measurements, the animals were killed and pulmonary tissue samples were harvested and snap frozen in liquid nitrogen and stored at $-80^{\circ} \mathrm{C}$ or, after overnight fixation, embedded in paraffin.

Morphometry. Pulmonary arterial morphometry was performed as reported previously $(4,5)$. MT was related to arterial size with the following formula: $\% \mathrm{MT}=(2 \times \mathrm{MT}) /(\mathrm{ED} \times 100)$, where $\mathrm{ED}$ means external diameter.

Real time quantification PCR. Pulmonary tissue mRNA levels were measured by SYBR Green RTQ-PCR for ET-1 and Ang-1/BMPR-2 pathways with primers previously reported $(4,5)$. To ensure the quality of the measurements, both negative and positive controls were systematically included in double, in each plate. The statistical analysis of the RTQ-PCR results was done using the $\Delta \mathrm{Ct}$ value ( $\mathrm{Ct}$ gene of interest $-\mathrm{Ct}$ reporter gene). Relative gene expression was obtained by $\Delta \Delta \mathrm{Ct}$ methods ( $\Delta \mathrm{Ct}$ sample $-\Delta \mathrm{Ct}$ calibrator) using the sham group as a calibrator, for comparison of every unknown samples genes expression levels. The conversion between $\Delta \Delta \mathrm{Ct}$ and relative gene expression levels is: Fold induction $=2^{-\Delta \Delta \mathrm{Ct}}(18)$. For the purpose of comparison, we measured with the same methods mRNA content for Ang-1, BMPR-1A, and BMPR-2 in lung tissue of sham, placebo-, and bosentantreated of previously reported piglets (4).

$\boldsymbol{R I A}$. Systemic arterial plasma ET-1 was measured by RIA after extraction as previously described $(4,5)$, using commercially available antibodies and tracers iodinated and HPLC purified in our laboratory.

Immunohistochemistry. The immunohistochemistry analysis was performed as previously reported $(4,5)$ with rabbit MAb to ET-1 (1/100 dilution) prepared in our laboratory. A mean OD, which relates to immunohistochemical staining intensity, was calculated for 20 pulmonary arteries of $<500 \mu \mathrm{m}$.

Statistical analysis. Values are reported as mean \pm SEM. Effects of the shunt and drugs were analyzed by a repeated measures ANOVA. When the F ratio of the ANOVA reached a $p<0.05$ critical value, Scheffe post hoc tests were performed to compare specific situations (19). Correlations were calculated via a linear regression analysis (19).

\section{RESULTS}

Weight averaged $40 \mathrm{~kg}$ and was not different in the three study groups. Arterial blood gases and hematocrits were normal and not different in the three study groups. The ratio of pulmonary to systemic flow before closure of the shunt was $1.9+0.1$ in the placebo group and $1.8+0.1$ in the sitaxsentan group $(p=\mathrm{NS})$.

Chronic systemic-to-pulmonary shunting increased $\mathrm{Ppa}_{\mathrm{m}}$, PVR, Ppao, Ees, and Ea without change in HR, Q, $\mathrm{Psa}_{\mathrm{m}}$, or the ratio of Ees to Ea (Table 1). The $\left(\mathrm{Ppa}_{\mathrm{m}}-\mathrm{Ppao}\right) / \mathrm{Q}$ relationships were shifted to higher pressures with an increase in slope (Fig. 1). There was an increase in pulmonary arterial

Table 1. Hemodynamic effects of preventive sitaxsentan treatment in overcirculation-induced experimental pulmonary arterial hypertension in piglets

\begin{tabular}{lccc}
\hline & & \multicolumn{2}{c}{ Shunt $(n=14)$} \\
\cline { 3 - 4 } & Sham & $\begin{array}{c}\text { Placebo } \\
(n=7)\end{array}$ & $\begin{array}{c}\text { Sitaxsentan } \\
(n=7)\end{array}$ \\
\hline $\mathrm{HR}($ beats/min $)$ & $105 \pm 8$ & $121 \pm 9$ & $113 \pm 5$ \\
$\mathrm{Q}(\mathrm{L} / \mathrm{min} / \mathrm{m})$ & $3.1 \pm 0.1$ & $3.2 \pm 0.1$ & $3.7 \pm 0.3$ \\
$\mathrm{Q}_{\mathrm{p}} / \mathrm{Q}_{\mathrm{s}}$ & - & $1.9 \pm 0.1$ & $1.8 \pm 0.1$ \\
$\mathrm{Psa}_{\mathrm{m}}(\mathrm{mm} \mathrm{Hg})$ & $134 \pm 5$ & $134 \pm 6$ & $140 \pm 4$ \\
$\mathrm{Ppa}_{\mathrm{m}}(\mathrm{mm} \mathrm{Hg})$ & $20 \pm 2$ & $35 \pm 1^{*}$ & $23 \pm 1$ \\
$\mathrm{PpaO}(\mathrm{mm} \mathrm{Hg})$ & $8 \pm 1$ & $11 \pm 1^{*}$ & $9 \pm 1$ \\
$\mathrm{PVR}(\mathrm{mm} \mathrm{Hg} / \mathrm{L} / \mathrm{min} / \mathrm{m})$ & $2.5 \pm 0.2$ & $6.3 \pm 0.3^{*}$ & $3.2 \pm 0.7 \dagger$ \\
Ees $(\mathrm{mm} \mathrm{Hg} / \mathrm{mL})$ & $1.37 \pm 0.11$ & $2.05 \pm 0.18^{*}$ & $1.13 \pm 0.14 \dagger$ \\
$\mathrm{Ea}(\mathrm{mm} \mathrm{Hg} / \mathrm{mL})$ & $0.90 \pm 0.08$ & $1.29 \pm 0.08^{*}$ & $0.78 \pm 0.14 \dagger$ \\
Ees/Ea & $1.55 \pm 0.08$ & $1.59 \pm 0.12$ & $1.59 \pm 0.14$ \\
\hline
\end{tabular}

Values are expressed as mean \pm SEM.

$* p<0.005$ sham $v s$ placebo; $\dagger p<0.005$ placebo $v s$ sitaxsentan.

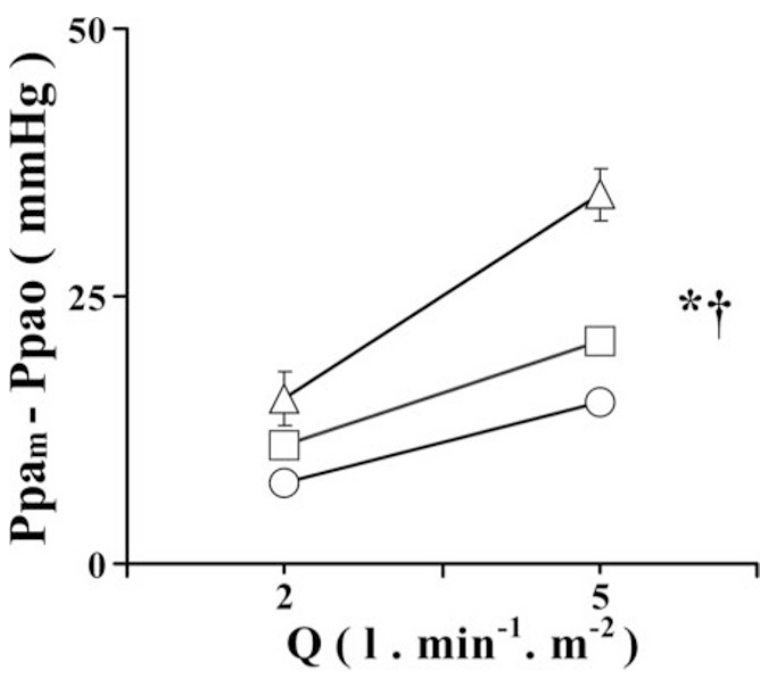

Figure 1. Composite plots of $\mathrm{Ppa}_{\mathrm{m}}$ minus balloon-occluded Ppa (Ppao) vs pulmonary blood flow $(\mathrm{Q})$ in sham, placebo-, and sitaxsentan-treated piglets. Sham-operated pigs $(\bigcirc)$; sitaxsentan-treated pigs $(\square)$; and placebo-treated pigs $(\triangle)$. Sitaxsentan partially prevented shunt-induced shift of $\left(\mathrm{Ppa}_{\mathrm{m}}-\right.$ Ppao)/Q plots to higher pressures. Values are expressed as mean \pm SEM. $* p$ $<0.005$ sham vs placebo; $\dagger p<0.005$ placebo vs sitaxsentan; $\ddagger p<0.005$ sham $v s$ sitaxsentan.

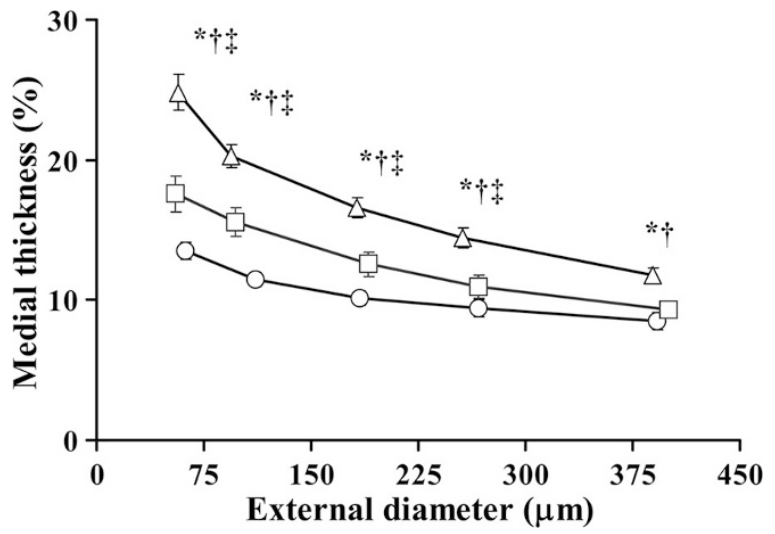

Figure 2. Morphometry on pulmonary arterioles of sham, placebo-, and sitaxsentan-treated piglets, and plot of \%MT vs external diameter (ED). Sham-operated pigs $(\bigcirc)$; sitaxsentan-treated pigs $(\square)$; and placebo-treated pigs $(\triangle)$. Sitaxsentan limited shunt-induced increase in MT to $36 \%$, and this effect was most pronounced in the smallest size arterioles. Values are expressed as mean \pm SEM. ${ }^{*} p<0.005$ sham $v s$ placebo; $\dagger p<0.005$ placebo vs sitaxsentan; $\ddagger p<0.005$ sham $v s$ sitaxsentan.

MT, and this effect was most pronounced in the smallest arterioles (Fig. 2). Plasma ET-1 increased, from $2.0 \pm 0.1$ $\mathrm{pg} / \mathrm{mL}$ in the sham operated controls to $3.8 \pm 0.5 \mathrm{pg} / \mathrm{mL}$ in placebo-treated animals $(p<0.05)$.

Sitaxsentan therapy prevented the increases in $\mathrm{Ppa}_{\mathrm{m}}$, Ppao, PVR, Ees, and Ea (Table 1) and partially prevented the shift to higher pressure of $\mathrm{Ppa}_{\mathrm{m}}-\mathrm{Ppao} / \mathrm{Q}$ relationships (Fig. 1). Sitaxsentan reduced the increase in pulmonary arterial MT by an average of $64 \%$ (Fig. 2). In the sitaxsentan-treated animals, plasma ET-1 was at $2.4 \pm 0.1 \mathrm{pg} / \mathrm{mL}(p=\mathrm{NS}$ versus sham-operated controls).

As illustrated in Figure 3, systemic-to-pulmonary shunting increased gene expressions for ET-1, ET-B receptor, ET converting enzyme (ECE-1), and Ang-1, decreased gene expres- 


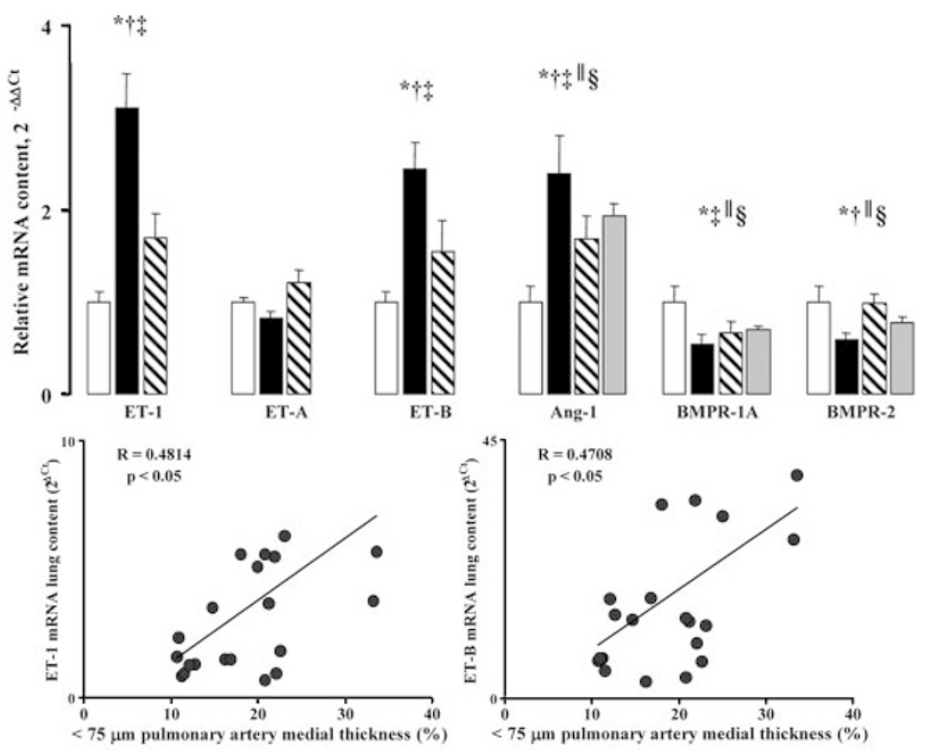

Figure 3. Relative lung tissue mRNA content for ET-1, ET-A and ET-B, Ang-1, BMPR-1A, and BMPR-2 of sham, placebo-, and sitaxsentan-treated piglets and correlations between lung mRNA content for ET-1, ET-B, Ang-1, BMPR-1A, and BMPR-2 and the percentage of MT for pulmonary arteries under $75 \mu \mathrm{m}$. White bar $=$ sham-operated pigs; black bar = placebo-treated pigs; hatched bar = sitaxsentan-treated pigs; gray $b a r=$ bosentan- treated pigs. Yet unreported relative lung tissue mRNA content for Ang-1, BMPR-1A, and BMPR-2 of bosentan-treated piglets from a previous study are also shown. Values are expressed as mean \pm SEM. $* p<0.005$ sham $v s$ placebo; $\dagger p<$ 0.005 placebo vs sitaxsentan; $\neq p<0.005$ sham vs sitaxsentan; $\| p<005$ sham vs bosentan; $\$ p<0.005$ placebo $v s$ bosentan.
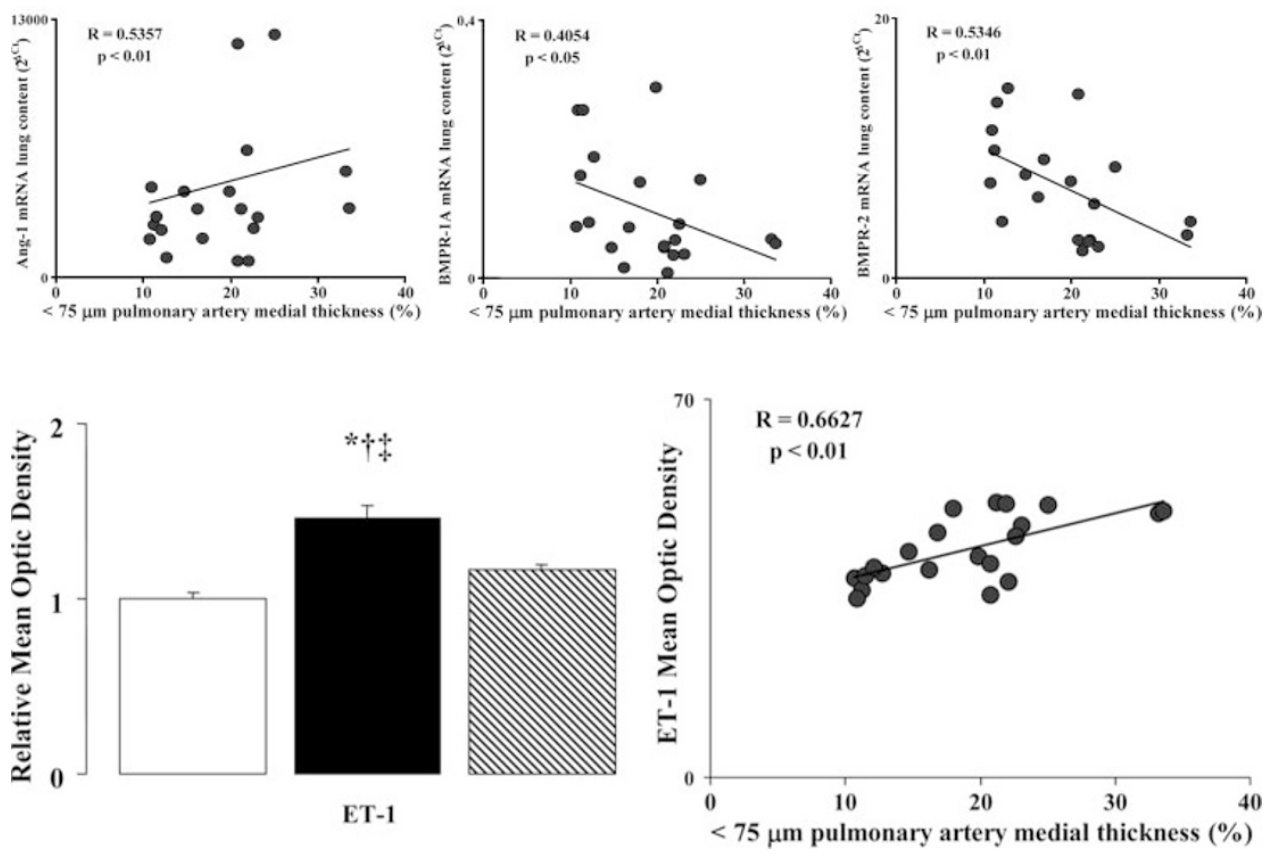

Figure 4. Bar graphs showing relative pulmonary arterial tissue protein content, as semi-quantitatively assessed by immunohistochemistry, for ET-1 of sham, placebo-, and sitaxsentan-treated and correlations between lung protein content for ET-1 and the percentage of MT for pulmonary arteries under $75 \mu \mathrm{m}$ Values are expressed as mean \pm SEM. White bar $=$ sham-operated pigs; black bar = placebotreated pigs; hatched bar $=$ sitaxsentantreated pigs. $* p<0.005$ sham $v s$ placebo; $\dagger p<0.005$ placebo $v s$ sitaxsentan; $\ddagger p<$ 0.005 sham vs sitaxsentan

sions for BMPR-1A, and BMPR-2, and did not change gene expressions for the ET-A receptor. Sitaxsentan therapy completely prevented changes in gene expressions for BMPR-2 and reduced the changes in gene expressions for ET-1, ET-B, ECE-1, Ang-1, and BMPR-1A. Statistical but weak correlations were observed between ET-1, ET-B, Ang-1, BMPR-1A, and BMPR-2 lung mRNA content and the percentage of MT of pulmonary arterioles under $75 \mu \mathrm{m}$.

In previously reported piglets (4), the nonselective ET-A/B receptor blocker bosentan decreased the changes in gene expressions for Ang-1, BMPR-1A , and BMPR-2 without returning any of them to normal (Fig. 3).

As illustrated in Figure 4, chronic left-to-right shunting increased pulmonary arterial immunostaining for ET-1, and this was reduced by sitaxsentan. There was a significant correlation between lung protein content of ET-1 and the percentage of MT of the smallest pulmonary arterioles.

\section{DISCUSSION}

The present results show that administration of sitaxsentan, a selective ET-A receptor antagonist, prevents overcirculation-induced PAH in piglets, by limiting hemodynamic and morphometric changes together with an improvement in dysfunctional ET-1 and BMP signaling pathways.

Chronic systemic to pulmonary shunting in growing piglets has been previously reported to be a realistic model for congenital cardiac shunt-induced PAH $(3-5,20)$. The piglet pulmonary circulation is exquisitely reactive, allowing for development in several weeks of high flow-induced hemodynamic and morphologic changes that would require decades in man (20). In the present study, 3 mo of aorta-pulmonary shunting in growing piglets caused severe pulmonary hypertension, with mean Ppa between 30 and $40 \mathrm{~mm} \mathrm{Hg}$ at a normal cardiac output, and pulmonary arteriolar medial hypertrophy, 
in keeping with previous reports (3-5). This corresponds to severe, though early and still reversible, disease (10), making this model suitable for the investigation of initial biologic changes.

The ET system is activated in patients with advanced PAH, who present with increased circulating levels of ET-1 (21-23) and an overexpression of lung tissue ET-1 (23). In overcirculation-induced $\mathrm{PAH}$, there is also an overexpression of the ET-B receptor, while the expression of the ET-A receptor remains unchanged $(4,5,13)$. In hypoxic pulmonary hypertension, both the ET-A and the ET-B receptors are overexpressed, and lung tissue ET-1 mRNA and circulating ET-1 are increased (24). In monocrotaline-induced pulmonary hypertension, circulating ET-1 is increased, but lung tissue ET-1 protein and mRNA are decreased (25). Thus, measurements of lung tissue mRNA and protein for ET-1 and its receptors may not always accurately reflect changes in the functional state of this signaling pathway in the development and perpetuation of pulmonary hypertension.

The development of potent, long-acting, and orally available nonselective and selective ET receptor antagonists has made it possible to explore the function of ET-1 receptor signaling in experimental and clinical pulmonary hypertension. Both nonselective ET-A/B and selective ET-A receptor blockers prevent and reverse hypoxic as well as monocrotaline-induced pulmonary hypertension (24-28), suggesting that the ET-A receptor is the major determinant of ET-1-mediated pathobiological changes in these two types of pulmonary hypertension. An alternative explanation would be that the endothelial and smooth muscle cell ET-B receptor functions remain balanced in $\mathrm{PAH}$, with reciprocal cancelling of proand antiproliferative and vasoconstrictive effects. In a face-toface comparison of the effects of selective ET-A and nonselective ET-A/B receptor blockade in monocrotaline-induced pulmonary hypertension, both treatments appeared equally effective in decreasing PVR, although there might have been an improvement in survival in the nonselective ET-A/B blocker group, possibly related to a lesser degree of right ventricular remodeling (29). However, in another study on monocrotaline-induced pulmonary hypertension, a more selective ET-A blocker and a nonselective ET-A/B blocker similarly decreased right ventricular systolic pressure and hypertrophy, which were aggravated by a selective ET-B receptor blocker (30). On the other hand, whether a limitation of right ventricular remodeling is beneficial in pulmonary hypertension is not established, as myocardial hypertrophy contributes to the adaptation of systolic function to increased afterload (31).

In the present experiments, the prevention of the increase in PVR, the remodeling of pulmonary arterioles, and associated biologic changes was similar to previously reported with bosentan (4) or sildenafil (5). In the same experimental conditions, the increase in small arteriole medial thickness was inhibited by $50 \%$ by sildenafil, $70 \%$ by bosentan, and $65 \%$ by sitaxsentan, whereas the increase in Ppa at a cardiac output of $4 \mathrm{~L} / \mathrm{min}$ was limited to $10 \%$ by sildenafil and bosentan and to $30 \%$ by sitaxsentan. This a posteriori comparison could suggest that the three interventions would be equally effective in the prevention of remodeling, but that sildenafil and bosentan could be more effective than sitaxsentan in the inhibition of vasoconstriction. It is possible that in early overcirculationinduced PAH, the ET-B receptor would contribute to ET-1induced vasoconstriction (32). However, because of a posteriori comparisons of effects in different studies, it is impossible from our data to conclude that any of the three drugs would be superior or inferior to the others in the prevention of shuntinduced PAH.

In overcirculation-induced PAH in lambs, selective ET-A receptor blockade has been reported to decrease PVR, without effect on arteriolar MT, without associated changes in plasma ET-1 or lung tissue preproendothelin-1, ET converting enzyme, and ET-A or ET-B receptor protein levels (33). It has to be noted that, in that study, pulmonary arteriolar MT was not increased compared with controls, suggesting very early purely vasospastic PAH (33), difficult to compare with more advanced overcirculation-induced PAH in piglets, where there is both vasoconstriction and remodeling (3).

The present results confirm that overcirculation-induced early PAH in piglets is associated with an overexpression of Ang-1 and a decreased expression of BMPR-1A (5), like reported in patients with advanced forms of severe pulmonary hypertension (34). They also confirm the early occurrence of a decreased expression of BMPR-2 (5), previously shown by semi-quantitative immunostaining in both idiopathic and congenital cardiac shunt induced PAH (35). In addition, in the present study, the gene expressions for ET-1, Ang-1, BMPR-1A, and BMPR-2 were all correlated to pulmonary arteriolar remodeling, which may suggest a positive interaction between ET, Ang-1, and BMP signaling in early PAH. It is of interest that the preventive application of therapies aimed at the restoration of endothelial vasodilator/constrictor equilibrium, either by the inhibition of phosphodiesteras- 5 by sildenafil (5) by inhibition of ET-A/B receptors by bosentan (4), or by inhibition of ET-A receptors by sitaxsentan, tend to return the expressions of Ang-1, BMPR-2, and BMPR-1A to normal. However, the nature of the interactions between these different pathways remains incompletely understood.

In the present study, right ventricular Ees, a loadindependent index of contractility, increased in proportion to $\mathrm{Ea}$, and that right ventriculoarterial coupling, estimated by a Ees/Ea ratio, remained unchanged, with and without treatment with sitaxsentan. This result confirms previous observations in the same model with preventive administration of bosentan. In patients with $\mathrm{PAH}$, right ventricular Ees is also increased, but Ees/Ea is decreased, indicating a decoupling of right ventricular function and right heart failure (31). In overcirculationinduced PAH in piglets, 3 mo of shunting does not appear sufficient to decouple the right ventricle from the hypertensive pulmonary circulation, and ET-1-receptor signaling does not appear to play a role in right ventricular systolic function adaptation.

In conclusion, the present study shows that sitaxsentan, a highly-selective ET-A receptor antagonist, partially prevents overcirculation-induced pulmonary hypertension in piglets, with a decrease in pulmonary vascular tone and in remodeling, and reverses the associated decrease in BMPR-2 expression, 
suggesting a significant participation of both endothelin receptor and BMP receptor signaling in the early stages of shunt-induced $\mathrm{PAH}$.

\section{REFERENCES}

1. Humbert M, Morrell NW, Archer SL, Stenmark KR, MacLean MR, Lang IM, Christman BW, Weir EK, Eickelberg O, Voelkel NF, Rabinovitch M 2004 Cellular and molecular pathobiology of pulmonary arterial hypertension. J Am Coll Cardiol 43:13S-24S

2. Farber HW, Loscalzo J 2004 Pulmonary arterial hypertension. N Engl J Med 351:1655-1665

3. Wauthy P, Kafi SA, Mooi WJ, Naeije R, Brimioulle S 2003 Effects of nitric oxide and prostacyclin in an over-circulation model of pulmonary hypertension. J Thorac Cardiovasc Surg 126:1430-1437

4. Rondelet B, Kerbaul F, Motte S, van Beneden R, Remmelink M, Brimioulle S, McEntee K, Wauthy P, Salmon I, Ketelslegers JM, Naeije R 2003 Bosentan for the prevention of overcirculation-induced experimental pulmonary arterial hypertension. Circulation 107:1329-1335

5. Rondelet B, Kerbaul F, Van Beneden R, Motte S, Fesler P, Hubloue I, Remmelink M, Brimioulle S, Salmon I, Ketelslegers JM, Naeije R 2004 Signaling molecules in overcirculation-induced pulmonary hypertension in piglets: effects of sildenafil therapy. Circulation 110:2220-2225

6. Arai H, Hori S, Aramori I, Ohkubo H, Nakanishi S 1990 Cloning and expression of a cDNA encoding an endothelin receptor. Nature 348:730-732

7. Zamora MA, Dempsey EC, Walchak SJ, Stelzner TJ 1993 BQ123, an ETA receptor antagonist, inhibits endothelin-1-mediated proliferation of human pulmonary artery smooth muscle cell. Am J Respir Cell Mol Biol 9:429-433

8. McCulloch KM, Docherty CC, Morecroft I, MacLean MR 1996 EndothelinB receptor-mediated contraction in human pulmonary resistance arteries. Br J Pharmacol 119:1125-1130

9. Davie N, Haleen SJ, Upton PD, Polak JM, Yacoub MH, Morrell NW, Wharton J 2002 ET(A) and ET(B) receptors modulate the proliferation of human pulmonary artery smooth muscle cells. Am J Respir Crit Care Med 165:398-405

10. Gratton JP, Cournoyer G, Loffler BM, Sirois P, D'Orleans-Juste P 1997 ET(B) receptor and nitric oxide synthase blockade induce $\mathrm{BQ}-123$-sensitive pressor effects in the rabbit. Hypertension 30:1204-1209

11. Dupuis J, Goresky CA, Fournier A 1996 Pulmonary clearance of circulating endothelin-1 in dogs in vivo: exclusive role of ETB receptors. J Appl Physiol $81: 1510-1515$

12. de Nucci G, Thomas R, D’Orleans-Juste P, Antunes E, Walder C, Warner TD, Vane JR 1988 Pressor effects of circulating endothelin are limited by its removal in the pulmonary circulation and by the release of prostacyclin and endothelium-derived relaxing factor. Proc Natl Acad Sci U S A 85:9797-9800

13. Black SM, Mata-Greenwood E, Dettman RW, Ovadia B, Fitzgerald RK, Reinhartz O, Thelitz S, Steinhorn RH, Gerrets R, Hendricks-Munoz K, Ross GA, Bekker JM, Johengen MJ, Fineman JR 2003 Emergence of smooth muscle cell endothelin B-mediated vasoconstriction in lambs with experimental congenital heart disease and increased pulmonary blood flow. Circulation 108:1646-1654

14. Rubin LJ, Badesch DB, Barst RJ, Galie N, Black CM, Keogh A, Pulido T, Frost A, Roux S, Leconte I, Landzberg M, Simonneau G 2002 Bosentan therapy for pulmonary arterial hypertension. N Engl J Med 346:896-903

15. Barst RJ, Langleben D, Frost A, Horn EM, Oudiz R, Shapiro S, McLaughlin V, Hill N, Tapson VF, Robbins IM, Zwicke D, Duncan B, Dixon RA, Frumkin LR, STRIDE-1 Study Group 2004 Sitaxsentan therapy for pulmonary arterial hypertension. Am J Respir Crit Care Med 169:441-447

16. Galie N, Badesch D, Oudiz R, Simonneau G, McGoon MD, Keogh AM, Frost AE, Zwicke D, Naeije R, Shapiro S, Olschewski H, Rubin LJ 2005 Ambrisentan therapy for pulmonary arterial hypertension. J Am Coll Cardiol 46:529-535
17. Davenport AP, Battistini B 2002 Classification of endothelin receptors and antagonists in clinical development. Clin Sci 103:1S-3S

18. Winer J, Jung CK, Shackel I, Williams PM 1999 Development and validation of real-time quantitative reverse transcriptase-polymerase chain reaction for monitoring gene expression in cardiac myocytes in vitro. Anal Biochem 270:41-49

19. Winer BJ, Brown DR, Michels KM 1991 Statistical Principles in Experimental Design, 3rd ed. McGraw-Hill, New York, pp 220-283

20. Rendas A, Lennox S, Reid L 1979 Aorta-pulmonary shunts in growing pigs Functional and structural assessment of the changes in the pulmonary circulation. J Thorac Cardiovasc Surg 77:109-118

21. Heath D, Edwards JE 1958 The pathology of hypertensive pulmonary vascular disease; a description of six grades of structural changes in the pulmonary arteries with special reference to congenital cardiac septal defects. Circulation 18:533-547

22. Yoshibayashi M, Nishioka K, Nakao K, Saito Y, Matsumura M, Ueda T, Temma S, Shirakami G, Imura H, Mikawa H 1991 Plasma endothelin concentrations in patients with pulmonary hypertension associated with congenital heart defects Evidence for increased production of endothelin in pulmonary circulation. Circulation 84:2280 2285

23. Giaid A, Yanagisawa M, Langleben D, Michel RP, Levy R, Shennib H, Kimura S, Masaki T, Duguid WP, Stewart DJ 1993 Expression of endothelin-1 in the lungs of patients with pulmonary hypertension. N Engl J Med 328:1732-1739

24. Li H, Chen SJ, Chen YF, Meng QC, Durand J, Oparil S, Elton TS 1994 Enhanced endothelin-1 and endothelin receptor gene expression in chronic hypoxia. J Appl Physiol 77:1451-1459

25. Miyauchi T, Yorikane R, Sakai S, Sakurai T, Okada M, Nishikibe M, Yano M, Yamaguchi I, Sugishita Y, Goto K 1993 Contribution of endogenous endothelin-1 to the progression of cardiopulmonary alterations in rats with monocrotaline-induced pulmonary hypertension. Circ Res 73:887-897

26. DiCarlo VS, Chen SJ, Meng QC, Durand J, Yano M, Chen YF, Oparil S 1995 ETA-receptor antagonist prevents and reverses chronic hypoxia-induced pulmonary hypertension in rat. Am J Physiol 269:L690-L697

27. Chen SJ, Chen YF, Meng QC, Durand J, Dicarlo VS, Oparil S 1995 Endothelin receptor antagonist bosentan prevents and reverses hypoxic pulmonary hypertension. J Appl Physiol 79:2122-2131

28. Hill NS, Warburton RR, Pietras L, Klinger JR 1997 Nonspecific endothelin-receptor antagonist blunts monocrotaline-induced pulmonary hypertension in rats. J Appl Physiol 83:1209-1215

29. Jasmin JF, Lucas M, Cernacek P, Dupuis J 2001 Effectiveness of a nonselective ETA/B and a selective ETA antagonists in rats with monocrotaline-induced pulmonary hypertension. Circulation 103:314-318

30. Nishida M, Eshiro K, Okada Y, Takaoka M, Matsumura Y 2004 Roles of endothelin ETA and ETB receptors in the pathogenesis of monocrotaline-induced pulmonary hypertension. J Cardiovasc Pharmacol 44:187-191

31. Kuehne T, Yilmaz S, Steendijk P, Moore P, Groenink M, Saaed M, Weber O, Higgins CB, Ewert P, Fleck E, Nagel E, Schulze-Neick I, Lange P 2004 Magnetic resonance imaging analysis of right ventricular pressure-volume loops: in vivo validation and clinical application in patients with pulmonary hypertension. Circulation 110:2010-2016

32. Sato K, Oka M, Hasunuma K, Ohnishi M, Sato K, Kira S 1995 Effects of separate and combined ETA and ETB blockade on ET-1-induced constriction in perfused rat lungs. Am J Physiol 269:L668-L672

33. Fratz S, Meyrick B, Ovadia B, Johengen MJ, Reinhartz O, Azakie A, Ross G, Fitzgerald R, Oishi P, Hess J, Black SM, Fineman JR 2004 Chronic endothelin A receptor blockade in lambs with increased pulmonary blood flow and pressure. Am J Physiol Lung Cell Mol Physiol 287:L592-L597

34. Du L, Sullivan CC, Chu D, Cho AJ, Kido M, Wolf PL, Yuan JX, Deutsch R, Jamieson SW, Thistlethwaite PA 2003 Signaling molecules in nonfamilial pulmonary hypertension. N Engl J Med 348:500-509

35. Atkinson C, Stewart S, Upton PD, Machado R, Thomson JR, Trembath RC, Morrell NW 2002 Primary pulmonary hypertension is associated with reduced pulmonary vascular expression of type II bone morphogenetic protein receptor. Circulation $105: 1672-1678$ 